\title{
Effect of baseline serum albumin concentration on outcome of resuscitation with albumin or saline in patients in intensive care units: analysis of data from the saline versus albumin fluid evaluation (SAFE) study
}

Saline versus Albumin Fluid Evaluation Study Investigators

\begin{abstract}
Objective To determine whether outcomes of resuscitation with albumin or saline in the intensive care unit depend on patients' baseline serum albumin concentration.

Design Analysis of data from a double blind, randomised controlled trial.

Setting Intensive care units of 16 hospitals in Australia and New Zealand.

Participants 6045 participants in the saline versus albumin fluid evaluation (SAFE) study.

Interventions Fluid resuscitation with $4 \%$ albumin or saline in patients with a baseline serum albumin concentration of $25 \mathrm{~g} / \mathrm{l}$ or less or more than $25 \mathrm{~g} / \mathrm{l}$.

Main outcome measures Primary outcome was all cause mortality at 28 days. Secondary outcomes were length of stay in the intensive care unit, length of stay in hospital, duration of renal replacement therapy, and duration of mechanical ventilation.

Main results The odds ratios for death for albumin compared with saline for patients with a baseline serum albumin concentration of $25 \mathrm{~g} / \mathrm{l}$ or less and more than $25 \mathrm{~g} / \mathrm{l}$ were 0.87 and 1.09 , respectively (ratio of odds ratios $0.80,95 \%$ confidence interval 0.63 to 1.02 ); $\mathrm{P}=0.08$ for heterogeneity. No significant interaction was found between baseline serum albumin concentration as a continuous variable and the effect of albumin and saline on mortality. No consistent interaction was found between baseline serum albumin concentration and treatment effects on length of stay in the intensive care unit, length of hospital stay, duration of renal replacement therapy, or duration of mechanical ventilation.

Conclusion The outcomes of resuscitation with albumin and saline are similar irrespective of patients' baseline serum albumin concentration.

Trial registration ISRCTN76588266.
\end{abstract}

\section{Introduction}

Intravenous fluid is fundamental to the management of patients in intensive care units. The two broad categories of fluid available are colloids and crystalloids. Among colloids, human albumin is unique in being a major human plasma protein that has important physiological roles. ${ }^{1-4}$ As hypoalbuminaemia is common in acute illness and is associated with an increased risk of death, ${ }^{5}$ the use of albumin to simultaneously treat hypoalbuminaemia and to increase intravascular volume seems intuitively attractive. A meta-analysis by the 1998 Cochrane Albumin Reviewers, however, suggested that giving albumin to critically ill patients for the treatment of both hypovolaemia and hypoalbuminaemia increased the risk of mortality. ${ }^{6}$ Subsequently the saline versus albumin fluid evaluation (SAFE) study reported no important difference in the overall risk of death for adults given albumin or saline for intravascular fluid resuscitation in intensive care units. ${ }^{78}$ In an updated meta-analysis incorporating data from the saline versus albumin fluid evaluation study, the Cochrane Injuries Group Albumin Reviewers concluded that there is no evidence that albumin reduces the risk of mortality in critically ill patients but a suggestion that it may increase the risk of death in patients with hypoalbuminaemia and burns. ${ }^{9}$ Thus while the saline versus albumin fluid evaluation study provides greater certainty over the effect of resuscitation with albumin or saline in a heterogeneous population of patients in intensive care units, effects in more selected populations of critically ill patients remain unknown. Using data from the saline versus albumin fluid evaluation study, we determined whether outcomes are influenced by baseline serum albumin concentration and whether either fluid can be recommended on the basis of patients' baseline serum albumin concentration.

\section{Methods}

Details of the saline versus albumin fluid evaluation study have been published elsewhere. ${ }^{78}$ The double blind, randomised controlled trial was carried out in the multidisciplinary intensive care units of 16 hospitals in Australia and New Zealand between November 2001 and June 2003.

Eligible adults were randomly assigned to receive either $4 \%$ albumin (Albumex; CSL, Melbourne, Australia) or normal saline for all fluid resuscitation in the intensive care unit until death, discharge, or 28 days after randomisation. Patients were excluded who had been admitted to the intensive care unit after cardiac surgery or liver transplantation or for the treatment of burns.

The primary outcome was all cause mortality within 28 days of randomisation. Secondary outcomes were length of stay in the intensive care unit, length of stay in hospital, duration of mechanical ventilation, and duration of renal replacement therapy.

Statistical analysis

We used $\chi^{2}$ tests for categorical variables and $t$ tests or analysis of variance for continuous variables to assess the association of 
baseline variables, including baseline albumin concentration, with mortality at 28 days. Baseline covariates were then fitted to logistic regression models to determine those independently associated with mortality.

We examined baseline albumin concentration as a binary variable using a predetermined cut-off ( $\leq 25 \mathrm{~g} / \mathrm{l}$ or $>25 \mathrm{~g} / \mathrm{l})$, and as a continuous variable. We assessed the effect of treatment allocation and baseline albumin concentration on 28 day mortality using logistic regression; we used the interaction between baseline albumin concentration and treatment assignment to examine whether the risk of death for those assigned to albumin compared with those assigned to saline was consistent between different baseline albumin concentrations. Initially we carried out the logistic regression without adjustment for other baseline risk factors; then adjusted for those covariates significant at the $\mathrm{P}<0.10$ level. We excluded central venous pressure and urine output owing to missing values (3136 for central venous pressure and 871 for urine output). We also examined the heterogeneity of treatment effect on the secondary outcomes of the saline versus albumin fluid evaluation study.

\section{Results}

The treatment groups had similar baseline characteristics, published previously. ${ }^{8}$ Data on baseline serum albumin concentration were available for 6045 patients, 3014 of those assigned to albumin and 3031 assigned to saline. No difference was found in the distribution of baseline serum albumin concentration by treatment group $(\mathrm{P}=0.76)$.

The distribution of baseline characteristics within each stratum of baseline albumin concentration ( $\leq 25 \mathrm{~g} / \mathrm{l}$ or $>25 \mathrm{~g} / \mathrm{l}$ ) was similar in those assigned to albumin and those assigned to saline (table 1).

Overall $2451(40.5 \%)$ patients had a baseline serum albumin concentration of $25 \mathrm{~g} / \mathrm{l}$ or less (1228 patients $(50.1 \%)$ in the albumin group and 1223 patients (49.9\%) in the saline group). Compared with patients with a baseline serum albumin concentration of more than $25 \mathrm{~g} / \mathrm{l} \quad(\mathrm{n}=3594)$, those with a concentration of $25 \mathrm{~g} / \mathrm{l}$ or less were older and were more likely to be admitted to the intensive care unit after surgery, more likely to have severe sepsis or acute respiratory distress syndrome, and less likely to have had traumatic brain injury. Severity of illness, as assessed by the acute physiology and chronic health evaluation II score ${ }^{10}$ was similar in patients with a baseline serum albumin concentration of $25 \mathrm{~g} / \mathrm{l}$ or less or more than $25 \mathrm{~g} / \mathrm{l}$ (table 2).

The primary outcome measure (mortality at 28 days) and baseline serum albumin concentration were available for 6040 $(99.9 \%)$ patients.

Baseline serum albumin concentration as both a binary and a continuous variable was independently associated with mortality. Other baseline factors independently associated with mortality were age, reason for admission to the intensive care unit, acute physiology and chronic health evaluation II score, liver and cardiovascular components of the sequential organ failure assessment score, ${ }^{11}$ mechanical ventilation at baseline, and heart rate $(\mathrm{P}<0.10)$.

After adjusting for baseline risk factors for death, a baseline serum albumin concentration of $25 \mathrm{~g} / \mathrm{l}$ or less was independently associated with risk of death (odds ratio 1.30, 95\% confidence interval 1.16 to $1.51, \mathrm{P}=0.0009)$. The findings were similar (table 3 ) when baseline serum albumin concentration was treated as a continuous variable (odds per $1 \mathrm{~g} / \mathrm{l}$ decrease in baseline serum albumin concentration $1.02,95 \%$ confidence interval 1.01 to $1.03, \mathrm{P}<0.0001)$.
Table 1 Baseline characteristics of patients in intensive care units assigned to albumin or saline, stratified by baseline serum albumin concentrations $(\leq 25 \mathrm{~g} / \mathrm{l}$ or $>25 \mathrm{~g} / \mathrm{l})$. Values are numbers (percentages) of patients unless stated otherwise

\begin{tabular}{|c|c|c|}
\hline Characteristic & Albumin group & Saline group \\
\hline \multicolumn{3}{|c|}{ Baseline serum albumin concentration $\leq 25 \mathrm{~g} / \mathrm{l}^{*}$} \\
\hline Mean (SD) age (years) & $61.5(18.4)$ & $61.1(17.7)$ \\
\hline Men & $725(59.0)$ & $715(58.5)$ \\
\hline $\begin{array}{l}\text { Admitted to intensive care unit for } \\
\text { postoperative care }\end{array}$ & $679(55.3)$ & $654(53.5)$ \\
\hline \multicolumn{3}{|l|}{ Present at baseline: } \\
\hline Traumatic brain injury & $52(4.2)$ & $46(3.8)$ \\
\hline Severe sepsis & $290(24.1)$ & $314(26.5)$ \\
\hline Acute respiratory distress syndrome & $33(2.7)$ & $45(3.7)$ \\
\hline $\begin{array}{l}\text { Mean (SD) acute physiology and chronic } \\
\text { health evaluation II score }\end{array}$ & $19.0(7.6)$ & $19.1(7.9)$ \\
\hline Mean (SD) urine output (ml/h) & $85.0(114.9)$ & $91.9(174.0)$ \\
\hline $\begin{array}{l}\text { Mean (SD) mean arterial pressure (mm } \\
\mathrm{Hg})\end{array}$ & $75.8(15.3)$ & $76.9(15.7)$ \\
\hline Receiving renal replacement therapy & $23(1.9)$ & $23(1.9)$ \\
\hline Receiving mechanical ventilation & $744(60.7)$ & $762(62.4)$ \\
\hline $\begin{array}{l}\text { Prior treatment with angiotensin } \\
\text { converting enzyme inhibitor }\end{array}$ & $163(13.3)$ & $159(13.1)$ \\
\hline \multicolumn{3}{|c|}{ Baseline serum albumin concentration $>25 \mathrm{~g} / \mathrm{l} \dagger$} \\
\hline Mean (SD) age (years) & $56.0(19.3)$ & $56.1(19.0)$ \\
\hline Men & $1064(59.6)$ & $1124(62.2)$ \\
\hline $\begin{array}{l}\text { Admitted to intensive care unit for } \\
\text { postoperative care }\end{array}$ & $576(32.3)$ & $599(33.1)$ \\
\hline \multicolumn{3}{|l|}{ Present at baseline: } \\
\hline Traumatic brain injury & $172(9.6)$ & $190(10.5)$ \\
\hline Severe sepsis & $251(14.4)$ & $254(14.4)$ \\
\hline Acute respiratory distress syndrome & $19(1.1)$ & $18(1.0)$ \\
\hline $\begin{array}{l}\text { Mean (SD) acute physiology and chronic } \\
\text { health evaluation II score }\end{array}$ & $19.0(8.0)$ & $19.4(8.1)$ \\
\hline Mean (SD) urine output (ml/h) & $92.4(140.5)$ & $97.1(157.8)$ \\
\hline $\begin{array}{l}\text { Mean (SD) mean arterial pressure (mm } \\
\mathrm{Hg})\end{array}$ & $79.7(16.8)$ & $79.5(16.2)$ \\
\hline Receiving renal replacement therapy & $19(1.1)$ & $16(0.9)$ \\
\hline Receiving mechanical ventilation & $1225(68.6)$ & $1230(68.0)$ \\
\hline $\begin{array}{l}\text { Prior treatment with angiotensin } \\
\text { converting enzyme inhibitor }\end{array}$ & $249(13.9)$ & 268 (14.9) \\
\hline
\end{tabular}

Patients assigned to albumin had a higher mean serum albumin concentration during the first seven days after randomisation (fig 1). This difference was apparent for patients with a baseline serum albumin concentration of $25 \mathrm{~g} / \mathrm{l}$ or less or more than $25 \mathrm{~g} / \mathrm{l}(\mathrm{P}<0.0001$ for both). On average, patients assigned to albumin received a lower daily volume of resuscitation fluid than patients assigned to saline (table 4).

\section{Patient outcomes}

Among patients with a serum albumin concentration of $25 \mathrm{~g} / \mathrm{l}$ or less, deaths occurred in 291 (23.7\%) assigned to albumin and 321 (26.2\%) assigned to saline (odds ratio $0.87,95 \%$ confidence interval 0.73 to $1.05, \mathrm{P}=0.14$ ). In patients with a serum albumin concentration of more than $25 \mathrm{~g} / \mathrm{l}$, deaths occurred in 353 $(19.8 \%)$ assigned to albumin and $334(18.5 \%)$ assigned to saline (odds ratio $1.09,95 \%$ confidence interval 0.92 to $1.28, \mathrm{P}=0.33$; fig 2 and table 5). The ratio of the odds ratios for patients with a baseline serum albumin concentration of $25 \mathrm{~g} / \mathrm{l}$ or less and of more than $25 \mathrm{~g} / \mathrm{l}$ was 0.80 (95\% confidence interval 0.63 to 1.02 ). After adjustment for baseline risk factors for death (table 3), the odds ratios for death of patients with a baseline serum albumin concentration of $25 \mathrm{~g} / \mathrm{l}$ or less and more than $25 \mathrm{~g} / \mathrm{l}$ given albumin compared with saline were 0.84 and 1.15 , respectively (ratio of odds ratios $0.73,95 \%$ confidence interval 0.55 to 0.97 ). The $\mathrm{P}$ 
Table 2 Comparison of baseline characteristics of patients in saline versus albumin fluid evaluation study with baseline serum albumin concentration $25 \mathrm{~g} / \mathrm{l}$ or less or more than $25 \mathrm{~g} / \mathrm{l}$. Values are numbers (percentages) of patients unless stated otherwise

\begin{tabular}{|c|c|c|c|}
\hline Characteristic & $\begin{array}{c}\text { Baseline serum } \\
\text { albumin } \\
\text { concentration } \leq 25 \mathrm{~g} / \mathrm{l} \\
(\mathrm{n}=2451)\end{array}$ & $\begin{array}{l}\text { Baseline serum } \\
\text { albumin } \\
\text { concentration }>25 \\
\mathrm{~g} / \mathrm{l}(\mathrm{n}=3594)\end{array}$ & $P$ value \\
\hline Mean (SD) age (years) & $61.3(18.0)$ & $56.1(19.1)$ & $<0.0001$ \\
\hline Men & $1440(58.8)$ & $2188(60.9)$ & 0.10 \\
\hline $\begin{array}{l}\text { Admitted to intensive care unit for } \\
\text { postoperative care }\end{array}$ & $1333(54.4)$ & $1175(32.7)$ & $<0.0001$ \\
\hline \multicolumn{4}{|l|}{ Present at baseline: } \\
\hline Traumatic brain injury & $98(4.0)$ & $362(10.1)$ & $<0.0001$ \\
\hline Severe sepsis & $604(24.6)$ & $505(14.1)$ & $<0.0001$ \\
\hline $\begin{array}{l}\text { Acute respiratory distress } \\
\text { syndrome }\end{array}$ & $78(3.2)$ & $37(1.0)$ & $<0.0001$ \\
\hline $\begin{array}{l}\text { Mean (SD) acute physiology and } \\
\text { chronic health evaluation II } \\
\text { score }\end{array}$ & $19.1(7.8)$ & $19.2(8.1)$ & 0.44 \\
\hline Mean (SD) urine output (ml/h) & $88.4(146.9)$ & $94.8(149.5)$ & 0.15 \\
\hline $\begin{array}{l}\text { Mean (SD) mean arterial pressure } \\
(\mathrm{mm} \mathrm{Hg})\end{array}$ & $76.4(15.5)$ & $79.6(16.5)$ & $<0.0001$ \\
\hline $\begin{array}{l}\text { Receiving renal replacement } \\
\text { therapy }\end{array}$ & $46(1.9)$ & $35(1.0)$ & 0.003 \\
\hline Receiving mechanical ventilation & $1506(61.4)$ & $2455(68.3)$ & $<0.0001$ \\
\hline $\begin{array}{l}\text { Prior treatment with angiotensin } \\
\text { converting enzyme inhibitor }\end{array}$ & $322(13.1)$ & $517(14.4)$ & 0.18 \\
\hline
\end{tabular}

values for heterogeneity of treatment effects between those with baseline serum albumin concentration of $25 \mathrm{~g} / \mathrm{l}$ or less and of more than $25 \mathrm{~g} / \mathrm{l}$ with and without adjustment for baseline risk

Table 3 Multivariate analysis of association of baseline characteristics (including baseline serum albumin concentration) and assigned group (albumin or saline) with risk of death

\begin{tabular}{|c|c|c|}
\hline Baseline characteristic & $P$ value & Odds ratio* $(95 \% \mathrm{CI})$ \\
\hline \multicolumn{3}{|l|}{ Albumin as binary variable: } \\
\hline Age & $<0.0001$ & 1.030 (1.025 to 1.035$)$ \\
\hline $\begin{array}{l}\text { Source of admission to intensive care } \\
\text { unit }\end{array}$ & $<0.0001$ & \\
\hline $\begin{array}{l}\text { Acute physiology and chronic health } \\
\text { evaluation II score }\end{array}$ & $<0.0001$ & 1.072 (1.061 to 1.083$)$ \\
\hline \multicolumn{3}{|l|}{$\begin{array}{l}\text { Sequential organ failure assessment } \\
\text { score: }\end{array}$} \\
\hline Liver component & $<0.0001$ & - \\
\hline Cardiovascular component & $<0.0001$ & - \\
\hline Mechanical ventilation & 0.001 & 1.326 (1.120 to 1.570) \\
\hline Heart rate & $<0.0001$ & 1.007 (1.003 to 1.010) \\
\hline $\begin{array}{l}\text { Baseline serum albumin concentration } \\
\text { as binary variable }\end{array}$ & 0.0009 & 0.772 (0.663 to 0.899$)$ \\
\hline Albumin $v$ saline group & 0.999 & 1.000 (0.869 to 1.151$)$ \\
\hline \multicolumn{3}{|l|}{ Albumin as continuous variable: } \\
\hline Age & $<0.0001$ & $1.030(1.025$ to1.034) \\
\hline $\begin{array}{l}\text { Source of admission to intensive care } \\
\text { unit }\end{array}$ & $<0.0001$ & \\
\hline $\begin{array}{l}\text { Acute physiology and chronic health } \\
\text { evaluation II score }\end{array}$ & $<0.0001$ & 1.072 (1.061 to 1.083$)$ \\
\hline \multicolumn{3}{|l|}{$\begin{array}{l}\text { Sequential organ failure assessment } \\
\text { score: }\end{array}$} \\
\hline Liver component & $<0.0001$ & - \\
\hline Cardiovascular component & $<0.0001$ & - \\
\hline Mechanical ventilation & 0.0008 & $1.334(1.126$ to 1.580$)$ \\
\hline Heart rate & 0.001 & 1.006 (1.003 to 1.010$)$ \\
\hline $\begin{array}{l}\text { Baseline serum albumin concentration } \\
\text { as continuous variable }\end{array}$ & $<0.0001$ & 0.979 (0.969 to 0.989) \\
\hline Albumin $v$ saline group & 0.944 & 0.995 (0.864 to 1.145$)$ \\
\hline
\end{tabular}

${ }^{*}$ For age, per one year increase in age; for acute physiology and chronic health evaluation II score, per one point increase in score; for heart rate, per one beat per minute increase in rate. factors (P values not adjusted for multiple comparisons) were 0.08 and 0.04 , respectively (fig 2 and table 5 ). When baseline serum albumin concentration was treated as a continuous variable, no significant interaction was found between baseline concentration and treatment assignment for 28 day mortality (unadjusted $\mathrm{P}=0.73$, adjusted $\mathrm{P}=0.94$ ). No significant interaction was found between baseline serum albumin concentration and treatment group for length of stay in the intensive care unit, duration of mechanical ventilation, and duration of renal replacement therapy ( $\mathrm{P}$ values $0.50,0.85$, and 0.33 , respectively), but an interaction of borderline significance was found for length of hospital stay $(\mathrm{P}=0.05$ without correction for multiple hypothesis testing; table 5).

\section{Discussion}

Our study does not provide evidence that the effect of resuscitation with albumin compared with saline in the intensive care unit is different in patients with different baseline serum albumin concentrations. Nor does it provide evidence to support the suggestion that albumin increases the risk of mortality in patients with hypoalbuminaemia. When the odds ratios for death was compared in patients with a baseline serum albumin concentration of $25 \mathrm{~g} / \mathrm{l}$ or less or of more than $25 \mathrm{~g} / \mathrm{l}$ we found only limited evidence that treatment effects were different and this only after correction for other baseline risk factors. When we considered the effect of baseline serum albumin concentration as a continuous variable across the spectrum of albumin concentrations, baseline concentration had no impact on the treatment effect even after correction for other baseline risk factors. Taken together these results suggest that albumin and saline produce similar treatment effects across the range of albumin concentrations observed in our study.

A recent meta-analysis assessed the effect of resuscitation with albumin or other fluids on outcomes other than mortality. The authors included 71 trials, which randomised 3782 acutely ill adults, children, and neonatal patients and concluded that albumin significantly reduced overall morbidity. ${ }^{12}$ This contrasts with the findings of the saline versus albumin fluid evaluation study in which there were no significant differences in morbidity in patients resuscitated with either albumin or saline. ${ }^{8}$ In the current analysis we found no interaction between baseline serum albumin concentration and choice of resuscitation fluid for length of stay in the intensive care unit, duration of renal replacement therapy, or duration of mechanical ventilation. We found borderline evidence of an interaction for length of hospital stay; patients with a baseline serum albumin concentration more than $25 \mathrm{~g} / \mathrm{l}$ who were resuscitated with albumin had a shorter hospital stay (mean difference 0.6 days). In the absence of any other significant heterogeneity, we interpret this as a chance finding.

The strengths of our study are the size and methodological strengths of the saline versus albumin fluid evaluation study, a double blind randomised controlled trial that has been recognised as a high quality landmark study and which contributed $82.8 \%$ of the data for the latest Cochrane meta-analysis. ${ }^{9}{ }^{13}$ The limitations are the inherent weaknesses of subgroup analyses and that the saline versus albumin fluid evaluation study was not primarily designed to determine the effect of treating hypoalbuminaemia with albumin. In the saline versus albumin fluid evaluation study, patients received the amount of fluid the treating clinician thought necessary to restore or maintain intravascular volume, and albumin was not given to achieve or maintain a particular serum albumin concentration. Patients assigned 

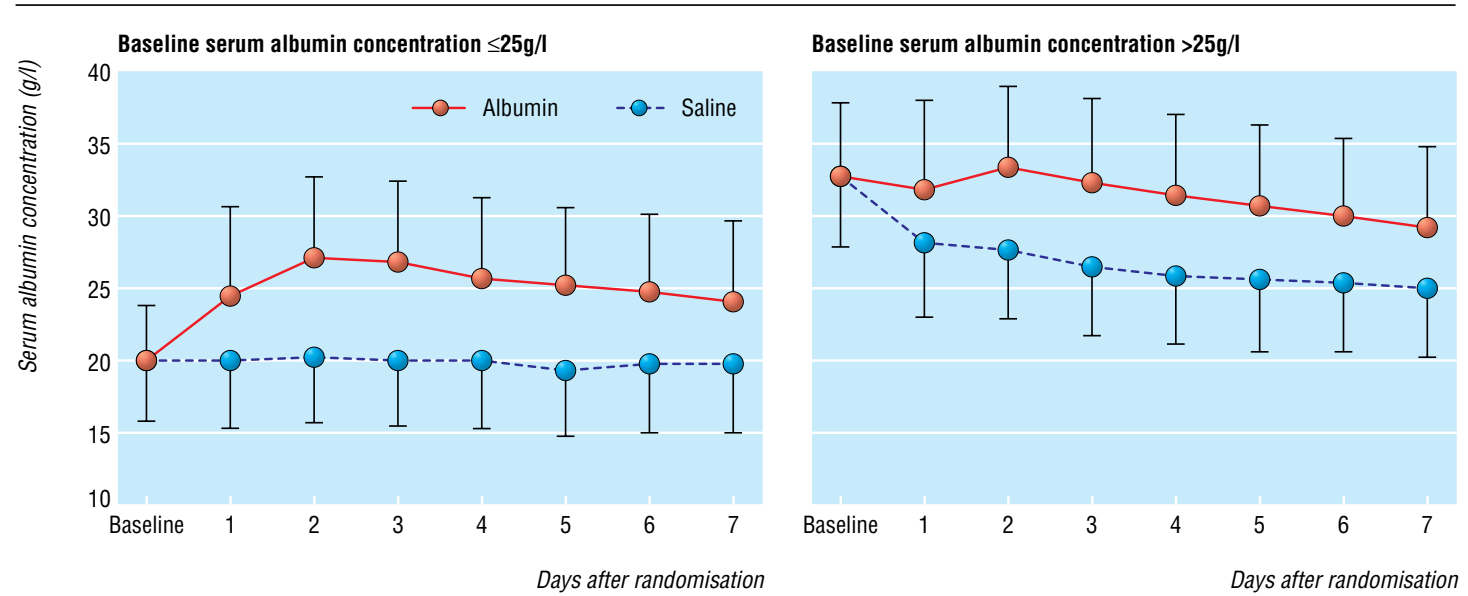

Fig 1 Effect of fluid resuscitation with albumin or saline on mean serum albumin concentration for seven days after randomisation stratified by baseline serum albumin concentration $(\leq 25 \mathrm{~g} / \mathrm{l}$ or $>25 \mathrm{~g} / \mathrm{l})$. Error bars indicate standard deviation

to albumin maintained higher serum albumin concentrations but this was not associated with clear benefit. Administering albumin to achieve and maintain a greater increase in serum albumin concentration, for instance to more than $30 \mathrm{~g} / \mathrm{l}$, has been advocated ${ }^{4}$; whether this would improve patients outcomes requires an appropriately designed trial. Although recognising the limitations of our analysis, the 2004 Cochrane review reported only 637 patients and 86 deaths from 10 trials of patients treated for hypoalbuminaemia; six trials (451 patients) were in adults. ${ }^{9}$ Of the 6997 adults in the saline versus albumin fluid evaluation study, 2451 had a recorded baseline serum albumin concentration of $25 \mathrm{~g} / \mathrm{l}$ or less of whom 612 died. Our analysis provides most of the available data on the effect of albumin administration to adults with hypoalbuminaemia in an intensive care unit, and so may provide a more reliable estimate of the treatment effect of albumin than the data on which the 2004 Cochrane review is based.

In conclusion, resuscitation with albumin and saline in the intensive care unit produces similar patient outcomes irrespective of patients' baseline serum albumin concentrations. Although albumin does not increase the risk of mortality, evidence is insufficient to support the routine use of albumin to maintain or increase intravascular volume in adults with hypoalbuminaemia in intensive care units. Whether administering albumin to adults in intensive care units to maintain a particular serum albumin concentration would be beneficial could only be answered by an appropriately designed trial. Our

Table 4 Volume of albumin or saline administered per day for first seven days in intensive care by treatment group and baseline serum albumin concentration

\begin{tabular}{|c|c|c|c|c|c|c|c|c|c|c|}
\hline \multirow[b]{2}{*}{ Day } & \multicolumn{4}{|c|}{ Baseline serum albumin concentration $\leq 25 \mathrm{~g} / \mathrm{l}$} & \multirow[b]{2}{*}{$\begin{array}{c}\text { P value } \\
\text { (albumin } v \\
\text { saline) }\end{array}$} & \multicolumn{4}{|c|}{ Baseline serum albumin concentration $>25 \mathrm{~g} / \mathrm{l}$} & \multirow[b]{2}{*}{$\begin{array}{c}\text { P value } \\
\text { (albumin } v \\
\text { saline) }\end{array}$} \\
\hline & $\mathrm{No}^{*}$ & $\begin{array}{c}\text { Mean (SD) } \\
\text { albumin } \\
\text { administered per } \\
\text { day (ml) }\end{array}$ & $\mathrm{No}^{*}$ & $\begin{array}{c}\text { Mean (SD) saline } \\
\text { administered per } \\
\text { day (ml) }\end{array}$ & & No* & $\begin{array}{c}\text { Mean (SD) } \\
\text { albumin } \\
\text { administered per } \\
\text { day (ml) }\end{array}$ & No* & $\begin{array}{c}\text { Mean }(\mathrm{SD}) \text { saline } \\
\text { administered per } \\
\text { day (ml }\end{array}$ & \\
\hline 1 & 1221 & $1217(981)$ & 1219 & $1650(1585)$ & $<0.0001$ & 1777 & $1154(970)$ & 1808 & $1470(1469)$ & $<0.001$ \\
\hline 2 & 1093 & 648 (973) & 1104 & $1211(1745)$ & $<0.0001$ & 1589 & $550(803)$ & 1621 & $752(1208)$ & $<0.0001$ \\
\hline 3 & 797 & $281(554)$ & 830 & $429(911)$ & $<0.0001$ & 1154 & $259(554)$ & 1158 & $290(617)$ & 0.21 \\
\hline 4 & 640 & 221 (449) & 642 & $312(846)$ & 0.02 & 859 & $179(420)$ & 870 & $171(456)$ & 0.71 \\
\hline 5 & 521 & $190(416)$ & 517 & 278 (674) & 0.01 & 708 & $183(448)$ & 723 & $173(463)$ & 0.68 \\
\hline 6 & 447 & $183(447)$ & 444 & 238 (617) & 0.13 & 593 & 164 (428) & 599 & 151 (486) & 0.61 \\
\hline 7 & 390 & 197 (474) & 390 & 241 (682) & 0.30 & 514 & 172 (469) & 514 & 131 (381) & 0.13 \\
\hline
\end{tabular}

Mean (standard deviations) rounded to nearest integer.

*Patients still in intensive care unit.

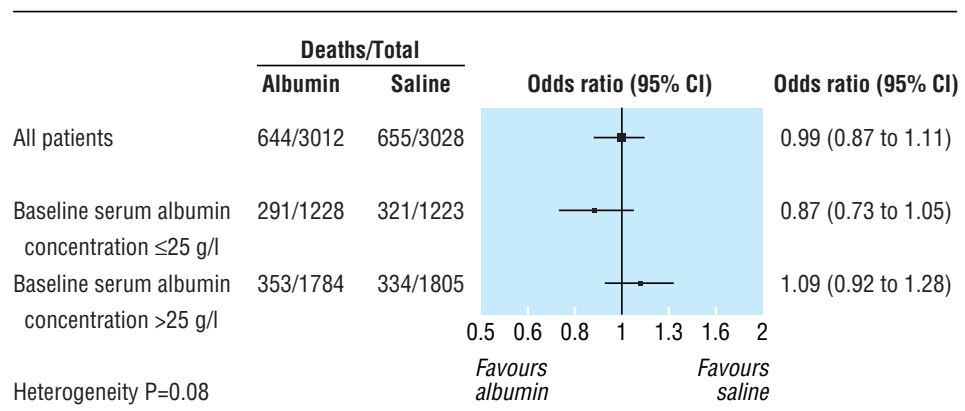

Fig 2 Unadjusted odds ratio (95\% confidence interval) of death in all patients and in subgroups with baseline serum albumin concentration of $25 \mathrm{~g} / \mathrm{l}$ or less and of more than $25 \mathrm{~g} / \mathrm{l}$. (Heterogeneity of treatment effect in subgroups with baseline serum albumin concentration $\leq 25 \mathrm{~g} / \mathrm{l} v>25 \mathrm{~g} / \mathrm{l}, \mathrm{P}=0.08$ ) 
Research

Table 5 Primary and secondary outcomes stratified by baseline serum albumin concentration $25 \mathrm{~g} / \mathrm{l}$ or less and more than $25 \mathrm{~g} / \mathrm{l}$. Values are means (standard deviations) unless stated otherwise

\begin{tabular}{|c|c|c|c|c|c|}
\hline Outcome & Albumin group & Saline group & Odds ratio $(95 \% \mathrm{Cl})$ & Absolute difference $(95 \% \mathrm{Cl})$ & $P$ value \\
\hline \multicolumn{6}{|l|}{ Baseline serum albumin $\leq 25 \mathrm{~g} / \mathrm{l}$} \\
\hline Status at 28 days: & $n=1228$ & $n=1223$ & - & - & - \\
\hline No $(\%)$ dead & $291(23.7)$ & $321(26.2)$ & $0.87(0.73$ to 1.05$)$ & - & 0.14 \\
\hline No (\%) alive in intensive care & $54(4.4)$ & $33(2.7)$ & 1.66 (1.07 to 2.58$)$ & - & 0.02 \\
\hline No (\%) alive in hospital & $333(27.1)$ & $322(26.3)$ & 1.04 (0.87 to 1.25$)$ & - & 0.66 \\
\hline $\begin{array}{l}\text { Length of stay in intensive care unit } \\
\text { (days) }\end{array}$ & $6.9(6.9)$ & $6.5(6.4)$ & - & $0.32(-0.21$ to 0.84$)$ & 0.24 \\
\hline Length of hospital stay (days) & $16.8(9.5)$ & $16.4(9.5)$ & - & $0.40(-0.35$ to 1.16$)$ & 0.30 \\
\hline $\begin{array}{l}\text { Duration of mechanical ventilation } \\
\text { (days) }\end{array}$ & $4.8(6.5)$ & $4.6(5.8)$ & - & $0.22(-0.27$ to 0.71$)$ & 0.37 \\
\hline $\begin{array}{l}\text { Duration of renal replacement therapy } \\
\text { (days) }\end{array}$ & $0.6(2.4)$ & $0.6(2.4)$ & - & $0.01(-0.18$ to 0.20$)$ & 0.89 \\
\hline \multicolumn{6}{|c|}{ Baseline serum albumin concentration $>25 \mathrm{~g} / \mathrm{l}$} \\
\hline Status at 28 days: & $\mathrm{n}=1784$ & $\mathrm{n}=1805$ & - & - & - \\
\hline No in group & 1784 & 1805 & - & - & - \\
\hline No $(\%)$ dead & $353(19.8)$ & $334(18.5)$ & 1.10 (0.92 to 1.28$)$ & - & 0.33 \\
\hline No (\%) alive in intensive care unit & $39(2.2)$ & $40(2.2)$ & 0.99 (0.63 to 1.54$)$ & - & 0.95 \\
\hline No $(\%)$ alive in hospital & $376(21.1)$ & $436(24.2)$ & 0.84 (0.73 to 0.98$)$ & - & 0.03 \\
\hline $\begin{array}{l}\text { Length of stay in intensive care unit } \\
\text { (days) }\end{array}$ & $6.2(6.3)$ & $6.2(6.2)$ & - & $0.09(-0.31$ to 0.50$)$ & 0.65 \\
\hline Length of hospital stay (days) & $14.4(9.5)$ & $15.0(9.7)$ & - & $-0.60(-1.23$ to 0.03$)$ & 0.06 \\
\hline $\begin{array}{l}\text { Duration of mechanical ventilation } \\
\text { (days) }\end{array}$ & $4.4(5.8)$ & $4.3(5.6)$ & - & $0.16(-0.21$ to 0.53$)$ & 0.39 \\
\hline $\begin{array}{l}\text { Duration of renal replacement therapy } \\
\text { (days) }\end{array}$ & $0.4(2.1)$ & $0.3(1.6)$ & - & $0.12(-0.00$ to 0.25$)$ & 0.05 \\
\hline
\end{tabular}

Ratio of odds ratios for death ( $95 \%$ confidence interval for ratio) for albumin versus saline with baseline serum albumin concentration $\leq 25 \mathrm{~g} / \mathrm{l} v>25 \mathrm{~g} / \mathrm{l}$; uncorrected 0.80 ( 0.63 to 1.02 ), corrected 0.73 ( 0.55 to 0.97$)$. P values for interaction terms (heterogeneity): (independent variables=treatment (albumin or saline) and baseline serum albumin $(\leq 25 \mathrm{~g} / \mathrm{l}$ or $>25 \mathrm{~g} / \mathrm{l})$ ). Mortality at 28 days: uncorrected $\mathrm{P}=0.08$, corrected $\mathrm{P}=0.04$. Length of stay in intensive care unit: uncorrected $\mathrm{P}=0.50$. Length of stay in hospital: uncorrected $\mathrm{P}=0.05$. Duration of mechanical ventilation: uncorrected $\mathrm{P}=0.85$. Duration of renal replacement therapy: uncorrected $\mathrm{P}=0.33$.

data suggest that any benefit (or harm) would be small and so a very large trial would be required.

Contributors: Investigators for the saline versus albumin fluid evaluation study are: writing committee-Simon Finfer (chair), Rinaldo Bellomo, Suzanne McEvoy, Sing Kai Lo, John Myburgh, Bruce Neal, and Robyn Norton; management committee-Robyn Norton (chair), Julie French (senior project manager), Rinaldo Bellomo, Simon Finfer, John Myburgh, Suzanne McEvoy, Gordon Doig, Mary Hayek, and Sheridan O'Donnell; steering committee-Simon Finfer (chair), Anthony Bell, Rinaldo Bellomo, Neil Boyce, David Blythe, John Cade, Marianne Chapman, Louise Cole, James Cooper, Andrew Davies, Craig French, Julie French, Christopher Joyce, Colin McArthur, Stephen MacMahon, John Myburgh, Bruce Neal, Robyn Norton, Jeffrey Presneill, Peter Saul, Ian Seppelt, Dianne Stephens, Andrew Turner, Anthony Williams, and Clive Woolfe; and external safety and data monitoring committee-Richard Peto (chair), Peter Sandercock, Charles Sprung, and J Duncan Young. The statistical analysis was carried out by Sing Kai Lo, Siva Sivarajasingham, Lesley Francis, and Mark Woodward (George Institute for International Health, University of Sydney, NSW). The site investigators were: Julie Charlton, James Cooper, Andrew Davies, Catherine Harry, Lisa Higgins, Katherine Moulden, and Shirley Vallance (Alfred Hospital, Melbourne, Vic); Janine Chadderton, Lynette Newby, and Colin

\section{What is already known on this topic}

Administering albumin may increase the risk of death in critically ill patients with hypoalbuminaemia

\section{What this study adds}

Irrespective of patients' baseline serum albumin concentration, fluid resuscitation with albumin or saline produced similar outcomes

Although albumin does not increase the risk of mortality in patients with hypoalbuminaemia, data do not support its routine use to maintain or increase intravascular volume in critically ill adults
McArthur (Auckland Hospital, New Zealand); Samantha Bates, Rinaldo Bellomo, Donna Goldsmith, and Alison Voss (Austin and Repatriation Medical Centre, Melbourne, Vic); Neil Boyce (Australian Red Cross Blood Service, Melbourne, Vic); David Blythe and Annamaria Palermo (Fremantle Hospital, WA); Lesley Francis, Julie French, Mary Hayek, Kathy Jayne, Stephen MacMahon, Mamta Merai, Bruce Neal, Robyn Norton, Sameer Pandey, Sheridan O'Donnell, Manuela Schmidt, Siva Sivarajasingham, and Mark Woodward (George Institute for International Health, University of Sydney, NSW); Rosemary Carroll, Brett McFadyen, and Peter Saul (John Hunter Hospital, Newcastle, NSW); Jane Clarke, Juliet Powell, Anthony Williams, and Judi Tai (Middlemore Hospital, Auckland, New Zealand); Louise Cole, Iveta Hynesova, Ian Seppelt, and Leonie Weisbrodt (Nepean Hospital, Penrith, NSW); Lisa Bradley, Christopher Joyce, Theresa Kelly, Anthony Limpus, and Robyn Moore (Princess Alexandra Hospital, Brisbane, Qld); Marianne Chapman, Stephanie Creed, Sandra Kaplan, and Justine Rivett (Royal Adelaide Hospital, SA); Dianne Stephens and Jane Thomas (Royal Darwin Hospital, NT); Anthony Bell, Kathy Marsden, and Andrew Turner (Royal Hobart Hospital, Tas); Catherine Boyce, John Cade, Belinda Howe, Jeffrey Presneill, and Megan Robertson (Royal Melbourne Hospital, Vic); Gordon Doig, Simon Finfer, Anne O'Connor, Julie Potter, and Naresh Ramakrishnan (Royal North Shore Hospital, Sydney, NSW); Catherine Powell, Dorrilyn Rajbhandari, and Clive Woolfe (Royal Prince Alfred Hospital, Sydney, NSW); Kathryn Girling, Marie Hodgetts, Alina Jovanovska, and John Myburgh (St George Hospital, Sydney, NSW); and Craig French and Lorraine Little (Western Hospital, Melbourne, Vic). The saline versus albumin fluid evaluation study is a collaboration of the Australian and New Zealand Intensive Care Society Clinical Trials Group, the Australian Red Cross Blood Service, and the George Institute for International Health. The writing committee will act as guarantor.

Funding: Auckland District Health Board, New Zealand; Australian Commonwealth Department of Health and Aged Care; CSL, Melbourne, Victoria; Middlemore Hospital, New Zealand; Australian National Health and Medical Research Council; Health Department of Western Australia; Health Research Council of New Zealand; New South Wales Health Department; Northern Territory Health Services; Queensland Health Services Department; Royal Hobart Hospital, Tasmania; South Australian Department of Human Services; and Victorian Department of Human Services

Competing interests: The saline versus albumin fluid evaluation study was part funded by CSL. CSL has acted as a sponsor for scientific meetings of the Australian and New Zealand Intensive Care Society and its clinical trials 


\section{Research}

group. CSL has paid travel expenses for Simon Finfer and Rinaldo Bellomo to present the results of the SAFE study at scientific and industry sponsored meetings. Andrew Davies and Diane Stephens own shares in CSL.

Ethical approval: This study was approved by the ethics committees of the University of Sydney and of each of the participating institutions.

1 Martin GS, Mangialardi RJ, Wheeler AP, Dupont WD, Morris JA, Bernard GR. Albumin and furosemide therapy in hypoproteinemic patients with acute lung injury. Crit Care Med 2002;30:2175-82.

2 Nicholson JP, Wolmarans MR, Park GR. The role of albumin in critical illness. Br J Anaesth 2000;85:599-610.

3 Quinlan GJ, Mumby S, Martin GS, Bernard GR, Gutteridge JM, Evans TW. Albumin influences total plasma antioxidant capacity favorably in patients with acute lung injury. Crit Care Med 2004;32:755-9.

4 Vincent JL, Dubois MJ, Navickis RJ, Wilkes MM. Hypoalbuminemia in acute illness: is there a rationale for intervention? A meta-analysis of cohort studies and controlled trials. Ann Surg 2003;237:319-34.

5 Goldwasser P, Feldman J. Association of serum albumin and mortality risk.J Clin Epidemiol 1997;50:693-703.

6 Cochrane Injuries Group Albumin Reviewers. Human albumin administration in critically ill patients: systematic review of randomised controlled trials. BMJ 1998;317:23540
7 ANZICS Clinical Trials Group and Institute for International Health SAFE Study Investigators. The saline vs. albumin fluid evaluation (SAFE) study (ISRCTN76588266): Design and conduct of a multi-centre, blinded randomised controlled trial of intravenous fluid resuscitation in critically ill patients. http://bmj.com/cgi/content/full/326/7389/559/DC1 (accessed 16 Mar 2006).

8 The SAFE Study Investigators. A comparison of albumin and saline for fluid resuscitation in the intensive care unit. N Engl J Med 2004;350:2247-56.

9 Human albumin solution for resuscitation and volume expansion in critically ill patients. Cochrane Database Syst Rev 2004;(4):CD001208.pub2.

10 Knaus WA, Draper EA, Wagner DP, Zimmerman JE. APACHE II: a severity of disease classification system. Crit Care Med 1985;13:818-29.

11 Vincent JL, de Mendonca A, Cantraine F, Moreno R, Takala J, Suter PM, et al. Use of the SOFA score to assess the incidence of organ dysfunction/failure in intensive care units: results of a multicenter, prospective study. Working group on "sepsis-related problems" results of a multicenter, prospective study. Working group on "sepsis-related problems"
of the European Society of Intensive Care Medicine. Crit Care Med 1998;26:1793-800. of the European Society of Intensive Care Medicine. Crit Care Med 1998;26:1793-800.
12 Vincent JL, Navickis RJ, Wilkes MM. Morbidity in hospitalized patients receiving 2 Vincent JL, Navickis RJ, Wilkes MM. Morbidity in hospitalized patients receiving
human albumin: a meta-analysis of randomized, controlled trials. Crit Care Med human albumin:

2004;32:2029-38.
Cook D. Is albumin safe? N Engl J Med 2004;350:2294-6.

(Accepted 12 September 2006)

doi $10.1136 /$ bmj.38985.398704.7C

Correspondence to: Professor S Finfer, Australian and New Zealand Intensive Care Society Clinical Trials Group, Carlton, Vic 3053, Australia sfinfer@george.org.au 